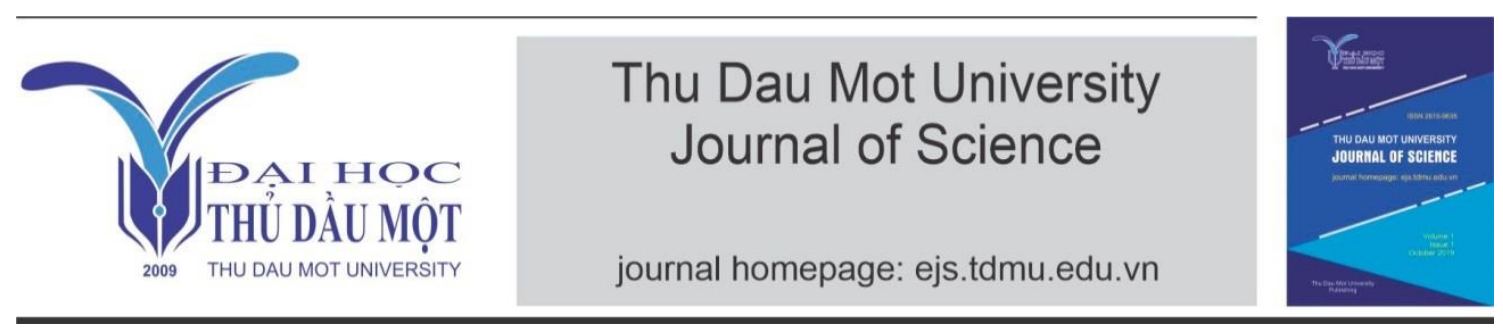

\title{
Assessment of environmental risk from polluted organic wastewater in Long Thanh Industrial Park with the Nemerow index and Principal component Analysis
}

\author{
by Le Nguyen Thanh Tri, Nguyen Hien Than (Thu Dau Mot University)
}

\author{
Article Info: $\quad$ Received 31 Jan. 2021, Accepted 2 June 2021, Available online 15 June 2021 \\ Corresponding author: thannh@tdmu.edu.vn \\ https://doi.org/10.37550/tdmu.EJS/2021.02.194
}

\begin{abstract}
This study aims to assess environmental risk using the improved Nemerow index and the principal component analysis (PCA) method in Long Thanh's Industrial Park in Dong Nai Province. The study was implemented in five industrial parks of Long Thanh District in 2019. The result showed that Loc An - Binh Son industrial park was at extreme high risk of the level (6.7). Three industrial parks of Long Thanh, Go Dau and An Phuoc were high-risk (from 3 to 5) respectively. On the other hand, Long Duc Industrial Park has obtained no environmental risk.
\end{abstract}

Keywords: environmental risk, Nemerow risk index, Long Thanh, PCA

\section{Introduction}

Water pollution is not able to affect human health immediately, but it also becomes significant damage during long-term exposure. Besides, water pollution also influenced the economic profits. The World Bank pointed out that every year in Vietnam, 780 million USD is lost in public health fields due to environmental pollution (Thủy, 2020).

Duong Thanh Nghi et al., (2011) studied "Evaluating bio-accumulation of persistent organic pollutants PCBS and PAHS in Ha Long Bay" the result in order to show the pollution level of PCBs, PAHs in the natural environment of water and sediments and their accumulation capacity in the biological flesh tissue is seasonal and increases gradually with the food chain. Inengite, Abasi, Walter, and Chemistry (2015) studied "Application of pollution indices to assess heavy metal pollution in flood affected soils" the results of Original Research Article the heavy metals revealed that heavy metals 
concentrations where higher in the flooded soil samples compared to the unflooded soil samples. There was also evidence of leaching of heavy metals. Zhang, Feng, and Hao (2018) studied "Applying the Nemerow index method and integrated water Quality index method in the water quality assessment of Zhangze Reservoir" the method is able to objectively reflect the water quality of each water quality monitoring section and is more suitable for the water quality evaluation of the reservoir. Sulthonuddin, Hartono, and Said (2019) studied "Using Nemerow's pollution index method for water Cimanuk River Quality Assessment in West Java" this research found that the Cimanuk river is not meet the water quality standards with the value of TSS $(81.57 \pm 132.69 \mathrm{mg} / \mathrm{L})$, BOD $(8.41 \pm 6.53 \mathrm{mg} / \mathrm{L})$, COD $(33.92 \pm 26.51 \mathrm{mg} / \mathrm{L})$, DO $(5.54 \pm 1.67 \mathrm{mg} / \mathrm{L})$, and Ammonia $(0.21 \pm 0.31 \mathrm{mg} / \mathrm{L})$. The degradation of river water quality in the Cimanuk river indicated by increasing NPI value, NPI value of the Cimanuk river ranging from 1.04 to 7.51 . The water quality status of the Cimanuk river has been changing from slightly to moderately polluted. Zhang, Hou, Qian, and ES (2020) studied "Water quality assessment using a comprehensive water quality index and revised Nemerow index method: A case study on Jinghui canal, North China" the results showed that groundwater quality in the area was poor due to the industrial and agricultural activities. Thus, the study on environmental risk assessment from industrial wastewater currently has been concerning areas, however the previous research was only focused on qualitative risk assessment or assessment of heavy metals risk. The Nemerow index has been carried out in many studies. However, the environmental risk assessment due to organic pollution integrated between the Nemerow risk index and the PCA weight has not been conducted yet. Therefore, this paper will implement an environmental risk assessment combining the Nemerow risk index and the PCA weight to quantitate the level of impact origin from organic pollution in industrial wastewater plants. The results of the study will illustrate a picture of the state of industrial wastewater treatment and the risk level of it. Furthermore, the results of the study will also provide basic information for authorities and local managers to adapt treatment technologies and input wastewater standards to improve industrial wastewater treatment efficiency.

\section{Materials and methods}

\section{The data of the study}

The data were collected from reports of wastewater monitoring of industrial parks in Long Thanh District in 2019. Each monitoring station, there is a frequency of 12 times per year. Five Industrial Parks by Go Dau Industrial Park, An Phuoc Industrial Park, Long Thanh Industrial Park, Loc An Industrial Park - Binh Son, Long Duc Industrial Park were chosen to study. Pollution parameters were observed in this study including $\mathrm{pH}$, total $\mathrm{N}$, total $\mathrm{P}$, total Ammonium, $\mathrm{BOD}_{5}, \mathrm{COD}$, and Fluoride. 


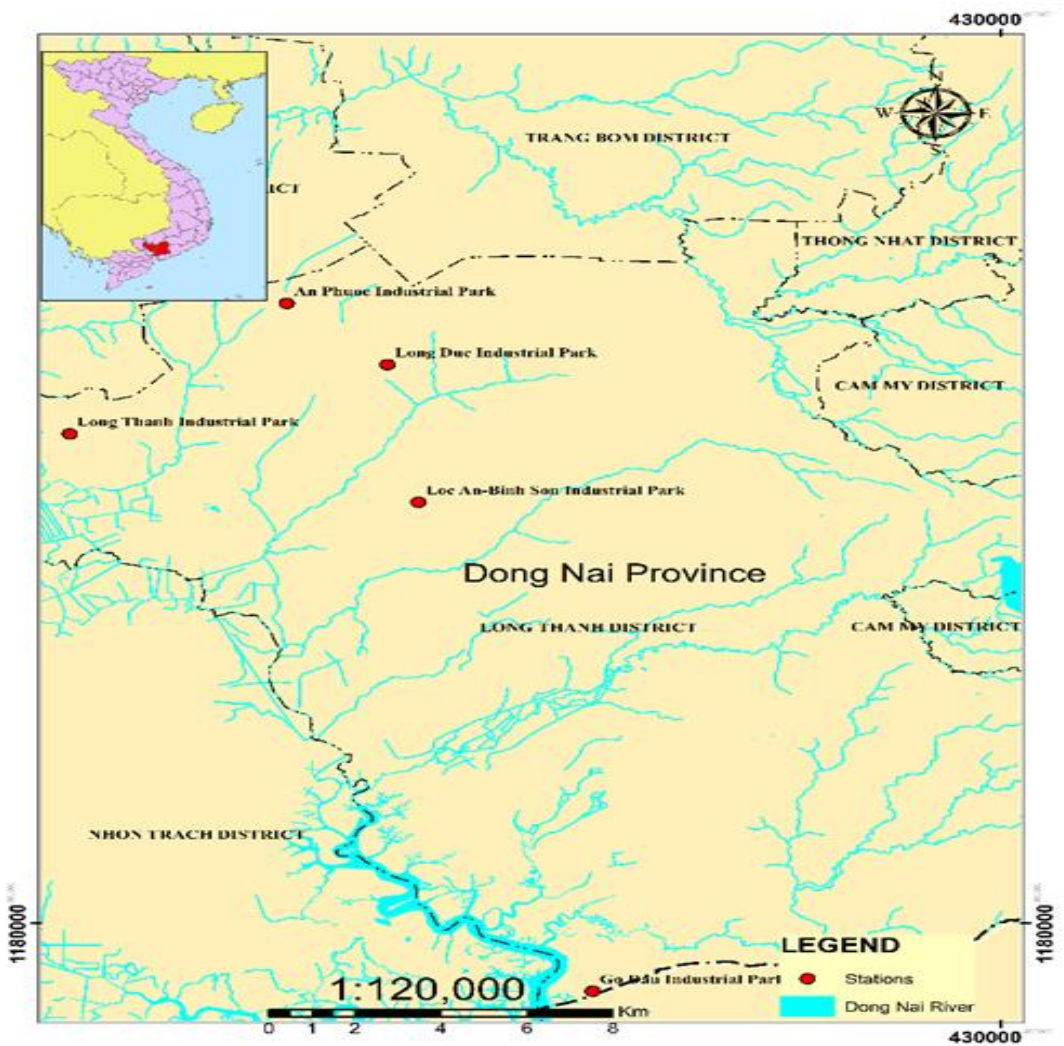

Figure 1. The map of sampling locations

\section{The Nemerow risk index}

In this study, the author used the Nemerow risk index to calculate the environmental risk from organic pollution of industrial wastewater. In 1974 the Nemerow index was published by NL Nemerow (Nemerow \& Leonard, 1974). Many studies use this index to evaluate the water quality as HaoYulin and GeZhenchang (1989), Islam, Ahmed, Raknuzzaman, Mamun, and Islam (2015). The assessment process is generalized as follows.

Step 1: Collecting monitoring data. In this study, data on wastewater monitoring of industrial parks in 2019 were used.

Step 2: Calculating the rate of exceeding standard and the level of wastewater pollution following the formula (Zhang et al., 2020):

According to traditional assessment, the Nemerow index is calculated by Eq 1. (A. K. Inengite, Abasi, \& Walter, 2015):

$P_{s}=\sqrt{\frac{P_{a v e}^{2}+P_{\max }^{2}}{2}}$

Of which:

$+\mathrm{P}_{\mathrm{s}}$ is the target of Nemerow pollution index 
$+\mathrm{P}_{\mathrm{ave}}$ is the average value of the single pollution index $(\mathrm{Pi})$ of each parameter.

$+\mathrm{P}_{\max }$ is the highest value of the parameter.

As stated in the evaluation formula, the weights of the pollution parameters are the same. However, the influence degree of parameters on wastewater quality is different according to many opinions of the studies. In this study, the weights of the pollutants were determined with the Entropy method. The formula for calculating the Nemerow risk index was modified as follows (QianZhang, Feng, \& Hao, 2018):

$$
P_{s}=\sqrt{\frac{\left(\mathrm{W}_{i} P_{i}\right)^{2}+P_{\max }^{2}}{2}}
$$

In which, $\mathrm{W}_{\mathrm{i}}$ is the weight of the i single pollutants.

The results of the Nemerow risk index are compared with the rating scale to determine the pollution level such as the water quality results are classified into 5 levels: Good $P$ $<1$, Caution $1<\mathrm{P}<2$, Medium risk $2<\mathrm{P}<3$, high risk $3<\mathrm{P}<5$, extreme high risk $\mathrm{P}>5$ (QianZhang et al., 2018; Tao, Yujia, \& Kai, 2011).

\section{Determining weights based on the principal components analysis (PCA)}

Principal components analysis groups together individual parameters that are collinear to form an overall index that obtains as much as possible of the information common to individual parameters. According to PCA, the weighting takes place only to correct for corresponding information between two or more correlated parameters, and is not a compute of the theoretical significance of the associated variables (Zhang et al., 2020). Steps for weighting parameters are as follows:

Step 1: Standardizing monitoring data

Step 2: Calculating the component score coefficient matrix

Step 3: Determining eigenvalues of the matrix

Step 4: Evaluating the variance contribution rate of principal components

Step 5: Implementing the rotation component matrix

Step 6: Computing weight for all parameters of pollutants.

Standard criteria choose loading factors that: (i) have associated initial eigenvalues larger than one; (ii) contribute individually to the explanation of overall variance by more than 10\%; and (iii) contribute cumulatively to the principal components of the overall variance by more than $60 \%$ (Zhang et al., 2020).

\section{Results and discussion}

The weights of parameters 
According to the result of the principal component analysis method, wastewater monitoring data obtained three principal components representing $82.68 \%$ of the variance of the sample with eigenvalue $>1$.

$T A B L E 1$. The eigenvalue and \% cumulative variance of the data

\begin{tabular}{lccccccc}
\hline & F1 & F2 & F3 & F4 & F5 & F6 & F7 \\
\hline Eigenvalue & 2.80 & 2.05 & 0.94 & 0.51 & 0.38 & 0.23 & 0.09 \\
\% variance & 39.94 & 29.30 & 13.44 & 7.29 & 5.44 & 3.34 & 1.24 \\
\% accumulation & 39.94 & 69.25 & 82.68 & 89.98 & 95.42 & 98.76 & 100 \\
\hline
\end{tabular}

As can be seen from Figure 2 and Figure 3 illustrated the first five-component account for $95.4 \%$ of the variance of the overall sample. Therefore, in this study, the first fivecomponents were chosen to determine the weight of the pollutants affecting the industrial wastewater quality. Besides, Figure 3 also showed that the Total Phosphorus was the highest load factor in the first-factor component, followed by Fluoride. In the second factor component, $\mathrm{BOD}_{5}$ and $\mathrm{COD}$ were the highest load factor.

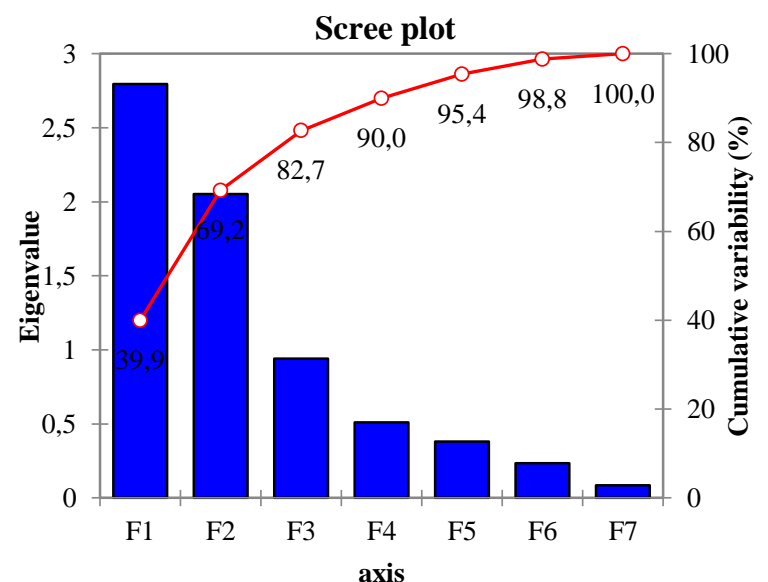

Figure 2. Diagram of eigenvalue and cumulative variance

TABLE 2. Squared load factors of parameters in the principal components

\begin{tabular}{lccccc}
\hline Thành phần & $\mathrm{D} 1$ & $\mathrm{D} 2$ & $\mathrm{D} 3$ & $\mathrm{D} 4$ & $\mathrm{D} 5$ \\
\hline $\mathrm{pH}$ & 0.0239 & 0.0458 & 0.0012 & $\mathbf{0 . 9 1 2 3}$ & 0.0085 \\
Nito Tổng & 0.0004 & 0.0535 & $\mathbf{0 . 9 3 9 9}$ & 0.0012 & 0.0002 \\
P tổng & $\mathbf{0 . 8 2 3 3}$ & 0.0061 & 0.0022 & 0.0058 & 0.0784 \\
Amoni & 0.1529 & 0.0026 & 0.0002 & 0.0089 & $\mathbf{0 . 8 3 2 7}$ \\
BOD 5 & 0.0003 & $\mathbf{0 . 9 4 3 2}$ & 0.0169 & 0.0058 & 0.0028 \\
COD & 0.0671 & $\mathbf{0 . 7 4 3 2}$ & 0.0644 & 0.0741 & 0.0012 \\
Florua & $\mathbf{0 . 6 0 8 3}$ & 0.0477 & 0.0215 & 0.0549 & 0.1280 \\
\% TLPS & 23.947 & 26.313 & 14.946 & 15.185 & 15.026 \\
\hline
\end{tabular}

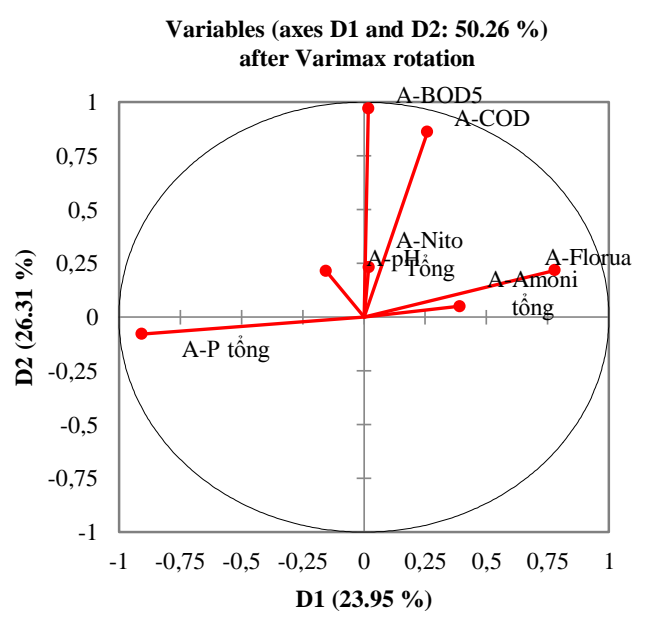

Figure 3. Load coefficients of parameters in Factor 1 and 2 TABLE 3. The Weights of variances

\begin{tabular}{lccccccc}
\hline $\begin{array}{c}\text { Thành } \\
\text { phần }\end{array}$ & $\mathrm{D} 1$ & $\mathrm{D} 2$ & $\mathrm{D} 3$ & $\mathrm{D} 4$ & $\mathrm{D} 5$ & $\begin{array}{c}\text { Tổng } \\
\text { hệ số }\end{array}$ & $\begin{array}{c}\text { Trọng } \\
\text { số }\end{array}$ \\
\hline $\mathrm{pH}$ & 0.0060 & 0.0126 & 0.0002 & 0.1452 & 0.0013 & 0.17 & 0.12 \\
Nito Tổng & 0.0001 & 0.0148 & 0.1472 & 0.0002 & 0.0000 & 0.16 & 0.11 \\
P tồng & 0.2066 & 0.0017 & 0.0003 & 0.0009 & 0.0124 & 0.22 & 0.16 \\
Amoni & 0.0384 & 0.0007 & 0.0000 & 0.0014 & 0.1311 & 0.17 & 0.12 \\
BOD5 & 0.0001 & 0.2601 & 0.0026 & 0.0009 & 0.0004 & 0.26 & 0.19 \\
COD & 0.0168 & 0.2049 & 0.0101 & 0.0118 & 0.0002 & 0.24 & 0.17 \\
Florua & 0.1527 & 0.0131 & 0.0034 & 0.0087 & 0.0202 & 0.20 & 0.14 \\
\% TLPS & 0.25 & 0.28 & 0.16 & 0.16 & 0.16 & & 1 \\
\hline
\end{tabular}


As we can see that the results of weighting calculation of pollutant parameters in wastewater obtained weighted values $(\mathrm{pH}, \mathrm{N}$-total, P-total, Amoni, BOD $5, \mathrm{COD}$, Florua $)=(0.12 ; 0.11 ; 0.16 ; 0.12 ; 0.19 ; 0.17 ; 0.14) . \mathrm{BOD}_{5}$ was the highest importance of elements affecting the industrial wastewater quality, then COD. Ph was recognized as the lowest contribution on the industrial wastewater quality.

\section{The current status of wastewater treatment of industrial parks}

There are five industrial parks in operation in Long Thanh District enclosing Go Dau Industrial Park, Long Duc Industrial Park, Long Thanh Industrial Park, An Phuoc Industrial Park, Loc An- Binh Son Industrial Park. Almost all industrial parks applying the main treatment technology are using the aerotank activated sludge, by contrast just only Loc An - Binh Son Industrial Park is applying treatment technology with SBR aerobic activated sludge. This technology is cheaper and capable of operation is steady. The treatment effectiveness is higher than other technologies.

The results of the wastewater treatment of the most industrial parks agree with QCVN 40:2011 of the Ministry of Natural Resources and Environment as the following describes.

\section{An Phuoc Industrial Park}

TABLE 4. Descriptive statistics of the wastewater quality of An Phuoc Industrial Park

\begin{tabular}{lccccccc}
\hline Statistic & $\mathbf{p H}$ & $\begin{array}{c}\text { N-total } \\
(\mathbf{m g} / \mathbf{l})\end{array}$ & $\begin{array}{c}\text { P-total } \\
(\mathbf{m g} / \mathbf{l})\end{array}$ & $\begin{array}{c}\text { Amoni } \\
(\mathbf{m g} / \mathbf{l})\end{array}$ & $\begin{array}{c}\text { BOD } \\
(\mathbf{m g} / \mathbf{l})\end{array}$ & $\begin{array}{c}\text { COD } \\
(\mathbf{m g} / \mathbf{l})\end{array}$ & $\begin{array}{c}\text { Floru } \\
\mathbf{a} \\
(\mathbf{m g} / \mathbf{l})\end{array}$ \\
\hline Min & 9.51 & 7.74 & 0.42 & 0.09 & 11.00 & 46.00 & 0.07 \\
Max & 10.04 & 9.98 & 0.67 & 0.22 & 12.00 & 48.00 & 0.24 \\
Mean & 9.78 & 8.86 & 0.55 & 0.16 & 11.50 & 47.00 & 0.16 \\
QCVN & & & & & & & \\
$\begin{array}{l}40: 2011 \\
\text { (Column A) }\end{array}$ & 7.2 to 10.8 & 24 & 4.8 & 6 & 36 & 90 & 6 \\
\hline
\end{tabular}

It can be seen from Table 3 and Figure 4, the observed parameters in An Phuoc Industrial Park were within the permitted limits of QCVN 40:2011 $\left(\mathrm{K}_{\mathrm{p}}=1.2, \mathrm{~K}_{\mathrm{f}}=1.0\right)$. Of which, only $\mathrm{pH}$ pollutant has exceeded the standard of 1,1156 . Thereby, it evidenced that the industrial wastewater treatment system of An Phuoc Industrial Park has handled monitoring

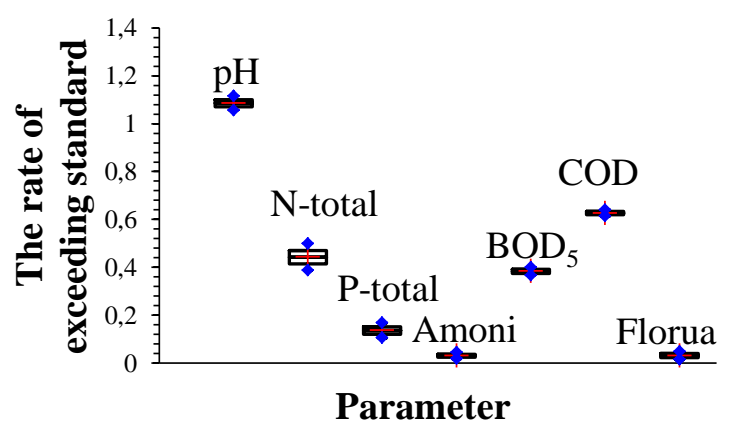

Figure 4. The rate of exceeding standards of An Phuoc Industrial Park parameters so well.

\section{Go Dau Industrial Park}


TABLE 5. Descriptive statistics of the wastewater quality of Go Dau Industrial Park

\begin{tabular}{lccccccc}
\hline Statistic & $\mathbf{p H}$ & $\begin{array}{c}\text { N-total } \\
(\mathbf{m g} / \mathbf{l})\end{array}$ & $\begin{array}{c}\text { P-total } \\
(\mathbf{m g} / \mathbf{l})\end{array}$ & $\begin{array}{c}\text { Amoni } \\
(\mathbf{m g} / \mathbf{l})\end{array}$ & $\begin{array}{c}\text { BOD } \\
(\mathbf{m g} / \mathbf{l})\end{array}$ & $\begin{array}{c}\text { COD } \\
(\mathbf{m g} / \mathbf{l})\end{array}$ & $\begin{array}{c}\text { Florua } \\
(\mathbf{m g} / \mathbf{l})\end{array}$ \\
\hline Min & 6.27 & 3.81 & 0.32 & 0.08 & 2.00 & 10.00 & 0.20 \\
Max & 7.31 & 15.00 & 0.74 & 1.30 & 8.00 & 31.00 & 0.65 \\
Mean & 6.81 & 7.08 & 0.48 & 0.23 & 4.92 & 18.00 & 0.39 \\
$\begin{array}{l}\text { QCVN } \\
\text { 40:2011 }\end{array}$ & 7.2 to 10.8 & 24 & 4.8 & 6 & 36 & 90 & 6 \\
(Column A) & & & & & & & \\
\hline
\end{tabular}

From Table 4 and Figure 5, we realized that the pollutants in Go Dau Industrial Park agreed within the limits of QCVN 40: $2011\left(\mathrm{~K}_{\mathrm{p}}=1.2, \mathrm{~K}_{\mathrm{f}}=1.0\right)$. It showed that the wastewater treatment system of Go Dau Industrial Park was good.

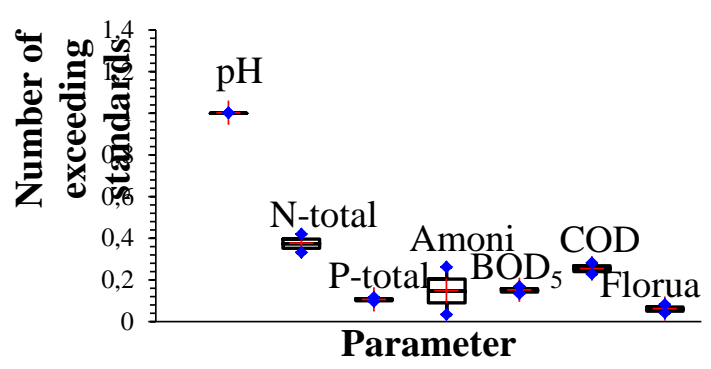

Figure 5. The rate of exceeding standards of Go Dau Industrial Park

\section{Loc An - Binh Son Industrial Park}

TABLE 6. Descriptive statistics the wastewater quality of of Loc An - Binh Son Industrial Park

\begin{tabular}{lccccccc}
\hline \multicolumn{1}{c}{ Statistic } & $\mathbf{p H}$ & $\begin{array}{c}\text { N-total } \\
(\mathbf{m g} / \mathbf{l})\end{array}$ & $\begin{array}{c}\text { P- } \\
\text { total } \\
(\mathbf{m g} / \mathbf{l})\end{array}$ & $\begin{array}{c}\text { Amoni } \\
(\mathbf{m g} / \mathbf{l})\end{array}$ & $\begin{array}{c}\text { BOD } \\
(\mathbf{m g} / \mathbf{l})\end{array}$ & $\begin{array}{c}\text { COD } \\
(\mathbf{m g} / \mathbf{l})\end{array}$ & $\begin{array}{c}\text { Florua } \\
(\mathbf{m g} / \mathbf{l})\end{array}$ \\
\hline Min & 6.09 & 14.80 & 0.94 & 0.00 & 8.00 & 25.00 & 0.00 \\
Max & 6.99 & 15.00 & 0.96 & 0.00 & 13.00 & 33.00 & 0.00 \\
Mean & 6.54 & 14.90 & 0.95 & 0.00 & 10.50 & 29.00 & 0.00 \\
$\begin{array}{l}\text { QCVN 40:2011 } \\
\text { Column A) }\end{array}$ & 7.2 to 10.8 & 24 & 4.8 & 6 & 36 & 90 & 6 \\
\hline
\end{tabular}

According to Table 5 and Figure 6 , it can be found that the observed parameters in Loc An - Binh Son Industrial Park adhered by the limit of QCVN 40: $2011\left(\mathrm{~K}_{\mathrm{p}}=1.2, \mathrm{~K}_{\mathrm{f}}\right.$ $=1.0)$. It indicated that the wastewater treatment system of Loc An- Binh Son Industrial Park has handled well monitoring parameters.

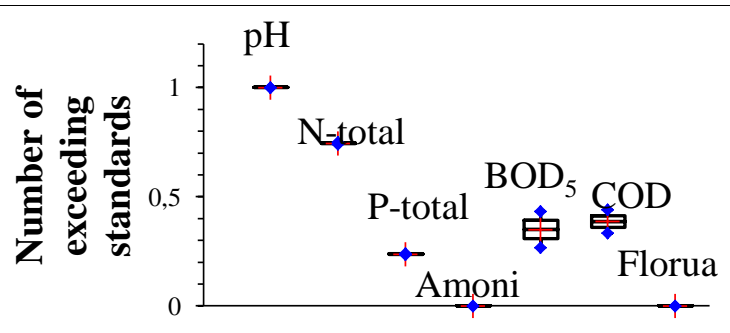

\section{Parameter}

Figure 6. Number of exceeding standards of Loc An Industrial Park - Binh Son 


\section{Long Duc Industrial Park}

TABLE 7. Descriptive statistics the wastewater quality of Long Duc Industrial Park

\begin{tabular}{lccccccc}
\hline \multicolumn{1}{c}{ Statistic } & $\mathbf{p H}$ & $\begin{array}{c}\mathbf{N}- \\
\text { total } \\
(\mathbf{m g} / \mathbf{l})\end{array}$ & $\begin{array}{c}\text { P-total } \\
(\mathbf{m g} / \mathbf{l})\end{array}$ & $\begin{array}{c}\text { Amoni } \\
(\mathbf{m g} / \mathbf{l})\end{array}$ & $\begin{array}{c}\text { BOD } \\
(\mathbf{m g} / \mathbf{l})\end{array}$ & $\begin{array}{c}\text { COD } \\
(\mathbf{m g} / \mathbf{l})\end{array}$ & $\begin{array}{c}\text { Florua } \\
(\mathbf{m g} / \mathbf{l})\end{array}$ \\
\hline Min & 6.96 & 5.33 & 0.19 & 0.30 & 4.00 & 13.00 & 0.43 \\
Max & 7.84 & 12.20 & 0.29 & 1.52 & 8.00 & 32.00 & 1.53 \\
Mean & 7.45 & 7.67 & 0.25 & 0.99 & 5.08 & 19.92 & 0.78 \\
$\begin{array}{l}\text { QCVN 40:2011 } \\
\text { Column A) }\end{array}$ & 7.2 to 10.8 & 24 & 4.8 & 6 & 36 & 90 & 6 \\
\hline
\end{tabular}

As can be seen from Table 6 and Figure 7 that Long Duc Industrial Park practised good wastewater treatment so that all pollutants were closed with QCVN 40:2011 ( $\mathrm{K}_{\mathrm{p}}=1.2, \mathrm{~K}_{\mathrm{f}}$ $=1.0$ ). This indicated that the effectiveness of the treatment plant was good performance.

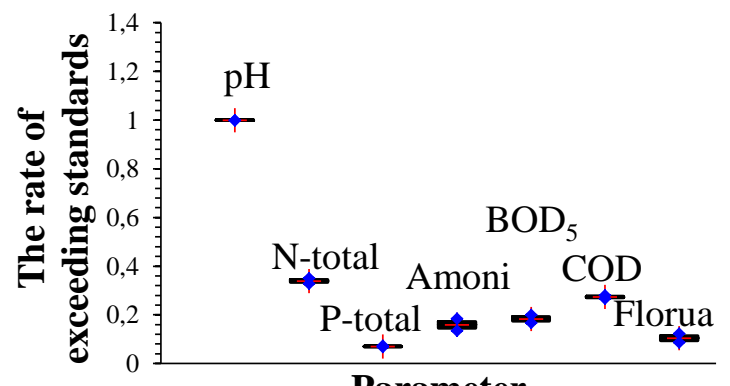

Parameter

Figure 7. The rate of exceeding standards of Long Duc Industrial Park

\section{Long Thanh Industrial Park}

TABLE 8. Descriptive statistics the wastewater quality of of Long Thanh Industrial Park

\begin{tabular}{|l|c|c|c|c|c|c|c|}
\hline \multicolumn{1}{|c|}{ Statistic } & $\mathbf{p H}$ & $\begin{array}{c}\text { N-total } \\
(\mathbf{m g} / \mathbf{l})\end{array}$ & $\begin{array}{c}\text { P-total } \\
(\mathbf{m g} / \mathbf{l})\end{array}$ & $\begin{array}{c}\text { Amoni } \\
(\mathbf{m g} / \mathbf{l})\end{array}$ & $\begin{array}{c}\text { BOD } \\
(\mathbf{m g} / \mathbf{l})\end{array}$ & $\begin{array}{c}\text { COD } \\
(\mathbf{m g} / \mathbf{l})\end{array}$ & $\begin{array}{c}\text { Florua } \\
(\mathbf{m g} / \mathbf{l})\end{array}$ \\
\hline Min & 7.77 & 6.95 & 0.09 & 0.48 & 7.00 & 36.00 & 0.76 \\
\hline Max & 8.10 & 15.90 & 0.25 & 1.72 & 15.00 & 48.00 & 1.36 \\
\hline Mean & 7.92 & 11.37 & 0.14 & 0.88 & 10.58 & 41.00 & 1.07 \\
\hline $\begin{array}{l}\text { QCVN 40:2011 } \\
\text { (Column A) }\end{array}$ & 6.48 to 9.72 & 21.6 & 4.32 & 5.4 & 32.4 & 81 & 5.4 \\
\hline
\end{tabular}

It can be seen from Table 7 and Figure 8 that the technology applied in the treatment plant achieved a good efficiency with QCVN $40: 2011\left(\mathrm{~K}_{\mathrm{p}}=1.2, \mathrm{~K}_{\mathrm{f}}=0.9\right)$.

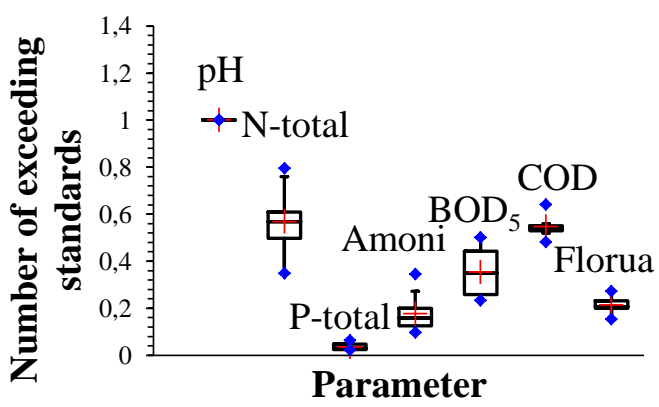

Figure 8. The rate of exceeding standards of Long Thanh Industrial Park 
In conclusion, it could be argued that the current treatment technology of almost industrial parks has a stable treatment efficiency. Most of the pollutants met in the limit of national technique regulation. Only the $\mathrm{pH}$ of An Phuoc Industrial Park exceeded the standard compared to QCVN 40: 2011/BTNMT.

The state of environmental risks from polluted organic wastewater in Long Thanh's industrial park

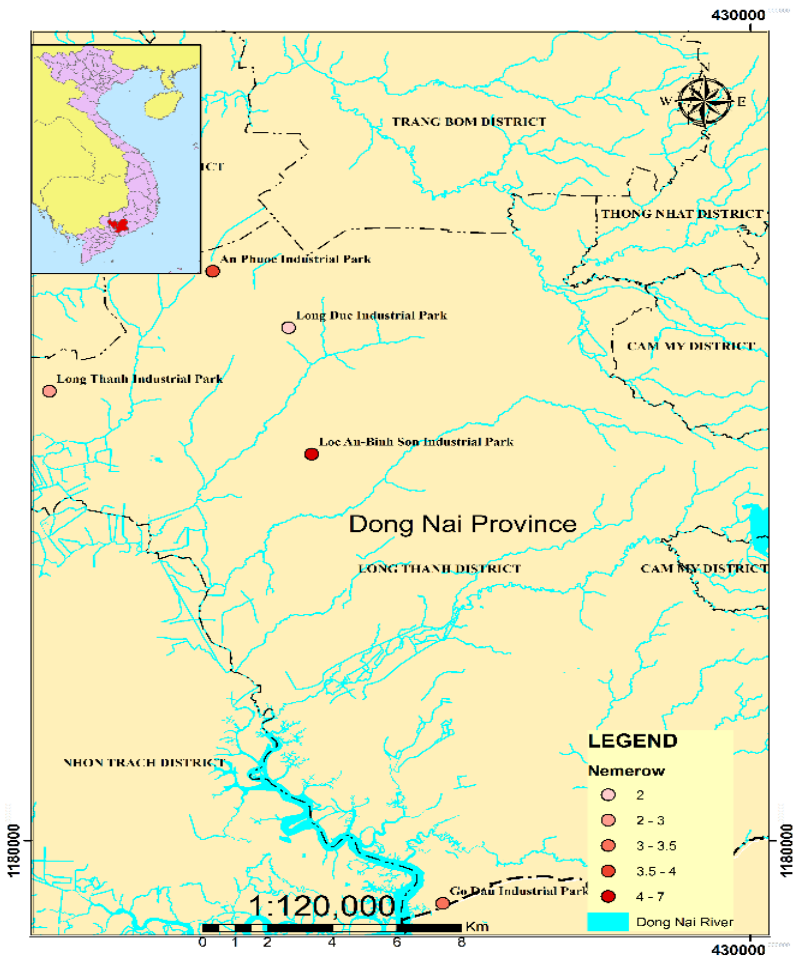

Figure 9. The risk level of Industrial Parks

To determine the current organic contaminants of each industrial park, we rely on National technical regulation on surface water quality QCVN 08-MT: 2015 / BTNMT. The purpose is to monitor a total load of pollutants discharged into the receiving waters through the basic parameters that determine the quality of water sources, thereby specifying the whole allowable maximum discharge load and discharge level for each waste source. Wastewater standards and regulations need to be built based on this basal purpose, including the feasibility of wastewater treatment methods and minimizing pollutants for the sustainability of the natural environment and the conservation of aquatic plants and animals in the habitat. Although the current state of the organic pollution of each industrial park, the results of the environmental risk from industrial parks.

TABLE 9. The Nemerow risk index of Long Thanh's industrial parks

\begin{tabular}{lc}
\hline \multicolumn{1}{c}{ Industrial Parks } & The risk level \\
\hline An Phuoc Industrial Park & 4.0 \\
Go Dau Industrial Park & 3.4 \\
Loc An - Binh Son Industrial Park & 6.7 \\
Long Duc Industrial Park & 2.5 \\
Long Thanh Industrial Park & 3.0 \\
\hline
\end{tabular}


As is shown by Table 8, Long Duc Industrial Park was the lowest risk (2.5), followed by Long Thanh Industrial Park (3.0) at caution level. Go Dau Industrial Park and An Phuoc Industrial Park were high level of 3.4, (4.0), Loc An - Binh Son Industrial Park was extremely high risk.

\section{Conclusion}

Although the development of the industrialization-modernization at Long Thanh's District Industrial Park brings many economic benefits, the environmental pollution problem also causes many consequences. The Nemerow risk index and PCA weights were good performance to evaluate the environmental risk causing wastewater. This study is the prerequisite to initiate studies on the handling of organic substances in industrial wastewater and to overcome problems from the dangers of organic substances.

\section{Acknowledgements}

This work is supported by Dong Nai Department of Natural Resources and Environment. The authors are grateful for editors and anonymous reviewers for their helpful and constructive comments on an earlier draft of this article.

\section{References}

HaoYulin, \& GeZhenchang (1989). Water quality evaluation for rivers of Xinjiang in China. Paper presented at the Regional Characterization of Water Quality, China.

Inengite, A., Abasi, C., Walter, C. J. I. R. J. o. P., \& Chemistry, A. (2015). Application of pollution indices for the assessment of heavy metal pollution in flood impacted soil. 175-189.

Inengite, A. K., Abasi, C. Y., \& Walter, C. (2015). Application of pollution indices for the assessment of heavy metal pollution in flood impacted soil. International research journal of pure \& applied chemistry, 8(5), 175-189.

Islam, M. S., Ahmed, M. K., Raknuzzaman, M., Mamun, M. H.-A.-., \& Islam, M. K. (2015). Heavy metal pollution in surface water and sediment: A preliminary assessment of an urban river in a developing country. Ecological Indicators, 48, 282-291. doi:http://dx.doi.org/10.1016/j.ecolind.2014.08.016

Nemerow, \& Leonard, N. (1974). Scientific stream pollution analysis.

Dương Thanh Nghị, Trần Đức Thạnh, Trần Văn Quy và Đỗ Quang Huy (2011). Đánh giá khả năng tích tụ sinh học chất ô nhiễm hữu cơ bền $\mathrm{PCBs}$ và $\mathrm{PAHs}$ vùng vịnh Hạ Long. Tuyển tập báo cáo Hội nghị Khoa học và Công nghệ Biển toàn quốc lần thứ $\mathrm{V}, 77$. 
QianZhang, Feng, M., \& Hao, X. (2018). Application of nemerow index method and integrated water quality index method in water quality assessment of Zhangze Reservoir. Earth and Environmental Science, 128, 1-6. doi: 10.1088/17551315/128/1/012160

Sulthonuddin, I., Hartono, D. M., \& Said, C. A. A. (2019). Using Nemerow's pollution index method for water quality assessment of Cimanuk River in West Java.

Tao, T., Yujia, Z., \& Kai, H. (2011). Water quality analysis and recommendations through comprehensive pollution index method. Management Science And Engineering, 5(2).

Thủy, V. T. D. (2020). Some solutions to complete regulations on waste management of the Law on Environmental Protection. Vietnamese Environment administration Magazine, 2.

Zhang, Q., Feng, M., \& Hao, X. (2018). Application of Nemerow index method and integrated water quality index method in water quality assessment of Zhangze Reservoir. Paper presented at the IOP Conf. Ser. Earth Environ. Sci.

Zhang, Y., Hou, K., Qian, H. J. E., \& ES. (2020). Water quality assessment using comprehensive water quality index and modified Nemerow index method: A case study of Jinghui Canal, North China. 467(1), 012125. 